6-3-2016

\title{
Book Review: Remembering Genocide
}

Tony Barta

LaTrobe University

Follow this and additional works at: https://digitalcommons.usf.edu/gsp

\section{Recommended Citation}

Barta, Tony (2016) "Book Review: Remembering Genocide," Genocide Studies and Prevention: An International Journal: Vol. 10: Iss. 1: 118-120.

DOI:

http://dx.doi.org/10.5038/1911-9933.10.1.1389

Available at: https://digitalcommons.usf.edu/gsp/vol10/iss1/12

This Book Review is brought to you for free and open access by the Open Access Journals at Digital Commons @ University of South Florida. It has been accepted for inclusion in Genocide Studies and Prevention: An International Journal by an authorized editor of Digital Commons @ University of South Florida. For more information, please contact digitalcommons@usf.edu. 
Book Review: Remembering Genocide

\author{
Tony Barta \\ La Trobe University \\ Melbourne, Victoria, Australia
}

Remembering Genocide

Nigel Eltringham and Pam Maclean, editors

London \& New York: Routledge, 2014

pp. 228; Cloth: \$150.00, Paperback: $\$ 44.95$

Reviewed by Tony Barta

La Trobe University, Melbourne

Recently in this journal I appealed for an opening up of genocide studies to embrace more disciplines and the approaches to understanding they might offer. My hope in "Liberating Genocide" (GSP Issue 9.2, pp. 103-119) was for a kind of inquiry that would shine a wide range of theoretical lights to help us illuminate actions, intentions, and contexts in ways we are already benefitting. I suggested that ethnographic history has demonstrated the utility and promise of such an approach. As I was trying to clarify these ideas I encountered a path-breaking collection of essays that engaged with one of the most pervasive and elusive problems of genocide studies; that is, the many questions raised by the term "memory." Commemoration and memorials take the questions into the future, whereas testimony and remembering take us back into terrible events and traumatic experience.

How do people who lived through it remember a genocide? What should we, who did not, remind ourselves to remember? Why should we remember? Who should remember? Where should we remember? Remembering Genocide addresses such key questions through a series of arresting case studies. Should we in Melbourne, for instance, remember the genocide so deeply felt by First Nations in Canada? It would not have occurred to me before I was a guest in Manitoba and listened to survivors of the Canadian Indian Schools. There I began to learn from Ted Fontaine, Tricia Logan, and others and was ashamed of my ignorance. I did not even remember that there had been a Canadian apology the same year as Prime Minister Rudd made the apology to the stolen generations in Australia. I was surprised that Stephen Harper had managed to say sorry for "kill the Indian in the child." Now, with Logan's chapter in this book, people far from Winnipeg can join her in remembering.

How do different ways of remembering work? As the editors remind us, memory is not a passive storage system, nor an image bank of the past, but an active, dynamic, shaping force. Raphael Samuel, whom the editors quote at the outset, says it is "historically conditioned to the emergencies of the moment... Like history, memory is inherently revisionist and never more chameleon than when it appears to remain the same" (1). We do tend to forget this, even as we recall its unreliability. In their sophisticated and sometimes provocative introduction, the editors raise yet more questions, all worth pondering. What is the relationship of memory to "truth"? Which kind of truth? What can we hear in testimony and in silence? Remembering an experience is very different from telling someone about it. The same memory cannot be passed on, not even by great art, and it cannot really be mediated. But art and media are all we have. Every commemoration has some art in its performance as does every medium, from concrete ruins to YouTube.

A book on memory is also a commemoration;-there is an act of commemorating in every chapter of this book. For instance, the violence in the separation of India and Pakistan; the 1915-1918 genocide of Turkish Armenians; two chapters on Rwanda along with two distinctively different chapters on remembrance of the Holocaust. There are two chapters that concern Australia where the colonial genocide receives the same searching and forthright treatment in ways similar to the Canadian case.

The persistent question of whether the atrocities of the Khmer Rouge in Cambodia were indeed a genocide is dealt straightforwardly by Elena Lesley-Rozen in "Memory at the site: Witnessing, education, and repurposing of Tuol Sleng and Choeung Elk in Cambodia" along with 
the issue of such atrocities bleeding into the present. All genocides carry into the present, as this book reminds us again and again. Henning Melber's argument in "Contested notions of genocide and commemoration: The case of the Herero in Namibia" makes it clear that the infamous case of German South West Africa is resolved neither in a present day reunited Germany nor in an independent Namibia.

When I say resolved I do not mean reconciled. Some authors here are more explicit than others about what the editors deal with under "utilitarian remembrance" (5). They nominate the "therapeutic" and "deterrent" uses of bringing up the past (5). There is little evidence that exhibiting earlier horrors has prevented later ones. But those of us who have direct experience of survivor testimony at memorial sites will also know that the hope of making a difference is an important part of the therapy guides can gain in bearing witness. Avril Alba's chapter, "Set in stone? The intergenerational and institutional transmission of Holocaust memory" has a special significance here as the generations change; as does Tricia Logan's chapter "National memory and museums: Remembering settler colonial genocide on the great Human Rights edifice in Winnipeg." The role therapy guides will play in healing First Nations wounds is far from resolved. The same of course is true in Australia. No-one will be surprised at how passionately I agree with Damien Short and his historical perspective on the open wound in our own country.

The activist starting point for this book begins with the observation that "critical to the process of countering genocide has been the desire that details of genocidal events, the victims and the worlds they inhabited are not forgotten" (1). Leaving aside the hope of countering future genocides, entering into the historical actualities of past events has to be the continuing challenge. It is a measure of quality that in every instance we want to take up the notes and bibliography to relive the horror of lives being violently ended. The chapters by Nicki Hitchcott "Memorial stories: Commemorating the Rwanda Genocide through fiction" and Nigel Eltringham "Bodies of evidence: Remembering the Rwandan Genocide at Murambi" take us into the technical school in Rwanda where some of the most terrible slaughter was committed. The photos of buildings in this book could be anywhere in Melbourne or Los Angeles direct us from the present memorializing into the history.

History, of course, is not memory. But the history will never contain the reality of atrocity if memory does not enable us to feel the calculation, the chaos, and the terror. Here we enter the realm of art and the ancient skills of narrative, image, and evocation. Pam Maclean's chapter "To be hunted like animals: Samuel and Joseph Chanesman remember their survival in the Polish countryside during the Holocaust" on two fugitives from the German murder machine is exemplary in its reworking of recollection into writing. In only a few pages she takes us into the fear, the mud, and the tension. Then she explores how the shared but individual experiences of father and son come through in very different styles of memory and retelling.

Tellers and interpreters rarely succeed without awareness of their audience and in this respect Remembering Genocide might have ventured further into debates on representation, ideology, and interests. Many contributions deal directly with the reception of the past in the present without penetrating far into the conventions and resistances of the public being addressed. I was caught by a reference to the consumption of what we produce (7). I argued in "Consuming the Holocaust" that we do have to worry; that the stories we tell, the commemorations we produce, do not just pass into patterns of media consumption. In the name Auschwitz we can recognize how a word becomes an image reinforced by the visual - as the Nazis knew when they banned photography in the death camps. In other cases, words provide the framing. In "No man's land' and the creation of partitioned histories in India/Pakistan" Pippa Virdee points out that the 1949 partition of India enters world history as "communal violence" rather than genocide (21). Popular representations (perhaps produced by Attenborough's film epic Gandhi) will not be interpreted as genocide unless reframed as she does here. Donna-Lee Frieze reminds us that our remembering is affected by the loss of an image track in "Three films, one genocide: Remembering the Rwanda Genocide through fiction." With her commentary on Ravished Armenia, Frieze restores some images that foreground

${ }^{1}$ Tony Barta, “Consuming the Holocaust: Memory Production and Popular Film," Contention Vol. 5, No.2. (Winter 1996): 161-175. 
gender in the Armenian genocide. In other chapters, too, the images, the photos, are important contributions; they help us engage with further historical questions they pose. Pam Maclean's chapter holds us to the very grammar of testimony, the halting or fluent deployment of words and images in painful recollections of Holocaust survival.

This is where the opening to other disciplines will pay dividends. We all readily accept that literary skill matters - in Primo Levi, in Paul Celan, in thousands of others. We tend to be less analytical about how other forms of media generate their power. One of the rewards of this book for me was the reopening of questions I had not much examined in the ways it represents events and memories. Screening the Past came out at an earlier stage of the hugely expanded memory scholarship referenced in Remembering Genocide, but I was reminded that some of the very earliest human communication capacities that film returned to after the heyday of print will remain fundamental in the new world of pervasive video. Reading faces and following spoken narrative return to centre stage. The sense experience of being caught up in the sense experience of anotherthis complex of the diegetic whole-will have to be further explored if we are to understand how narratives, images, and memorial sites work their effects.

Recollections, re-collections. There are now millions of recordings, voices, videos, films, books, websites, memorial sites, museums, names on monuments, schoolrooms, killing fields, skulls behind glass. When is too much remembering not enough, when is not enough memory already too much? Am I right in thinking Raphael Lemkin himself recorded Simon Dubnow's command "Schreibt und farschreibt," write and record? To what end? As Alba says, that may be debated, after Dubnow's first essential step.

I like the title of Ernesto Verdeja's book Unchopping a Tree: Reconciliation in the Aftermath of Political Violence ${ }^{2}$. We cannot unchop a tree. We cannot bring back the dead. But in a book such as this we remember them, in too many places where even the remembering is fraught. We owe these authors a debt for helping us to go there.

${ }^{2}$ Ernesto Verdeja, Unchopping a Tree: Reconciliation in the Aftermath of Political Violence, (Philadelphia, PA: Temple University Press, 2009). 